\title{
China Inward FDI and Chinese Exports to High-Income Countries (HICs): A Historical Perspective Based on Bibliometric Method
}

\author{
Eurico Brilhante Dias ${ }^{1} \&$ Kristina Makalengva ${ }^{1}$ \\ ${ }^{1}$ Business Research Unit, ISCTE-Lisbon University Institute, Lisbon, Portugal \\ Correspondence: Eurico Brilhante Dias, ISCTE-Lisbon University Institute, Avenida das Forças Armadas, cac. \\ 301, 1649-026, Lisbon, Portugal. Tel: 351-21-7903412. E-mail: eurico.dias@iscte.pt
}

Received: October 14, 2013

Accepted: October 25, 2013

Online Published: November 22, 2013

doi: 10.5539/ibr.v6n12p17

URL: http://dx.doi.org/10.5539/ibr.v6n12p17

\begin{abstract}
PR China is capturing FDI mainly from the overseas Chinese territories and from High-Income Countries (HICs); this last group is also the most important Chinese export-market. Adopting an inductive methodology, based on the bibliometric method, our purpose is the understanding of which were the determinants that led to attract inward FDI and, later, to increase exports from PR China to HICs. Taking into account the time frame 1980-2010, 367 different publications were collected. Using the ISI Web of Science and the HistCite Software 10 research papers were the basis for a bibliometric diagram (LCS $>$ or equal to 5). From this diagram was possible to extract two main streams: economic reforms toward an inward FDI attraction and world exports leadership; and inward FDI - mainly from HICs - led to an increasing value of the exports basket. A third issue emerged also, not as a stream, but as an important conclusion based on the Gilboy (2004) paper, published on Foreign Affairs: foreign companies dominate high-tech industries and a lion's part of Chinese industrial exports. PR China has reached the world exporting ranking leadership based on economic reforms, focused on the attraction of FDI export driven, which had on companies from HICs a major contribution.
\end{abstract}

Keywords: inward FDI, Chinese economic reforms, exports, bibliometric method

\section{Introduction}

People's Republic of China (PR China), since the end of the last decade, has become the largest exporter in the World (World Bank, 2012; Economist Intelligence Unit, 2012). A remarkable leadership, based on a rising trend, which begun in the late 70's of the last century. Several authors relate this leadership with three main issues: economic reforms since 1978, with Deng Xiaoping Communist Party of China (CPC) leadership; an economic policy toward foreign direct investment (FDI) attraction; and, an exporting oriented policy.

A sustainable growth, where FDI, exports and economic development were (are) "mutually reinforcing under the open-door policy" (Liu, Burridge \& Sinclair, 2002); an economic growth which has been leveraged by the inputs expansion (Krugman, 1994) - capital and labor-which gives to FDI attraction an important role in the last 30 years of the Chinese economy history (Dunning, 2003). Additionally, as it was mentioned by Markusen (1995), among others, these new resources were focused, and used, to serve not only the domestic Chinese market, but mainly foreign demand, as part of global or international value chains (vertical FDI-Buckley, Clegg \& Wang, 2002).

Thus, this context has been the focus, and was under the spotlight, of several economic and international business researchers. PR China became a field of research, where FDI attraction determinants, exporting oriented policies, the impact of economic reforms or the Chinese WTO membership, were topics discussed, and the academic community and some practioners have given awareness to the key factors that led this country to a long and steady growth uptrend. Following this common work, where many researchers have made their contribution, and based on the bibliometric method, Fetscherin et al. (2010) have published a research paper where defined four research streams related with FDI into PR China, considering the time range between 1980 and 2010; a time range which considers the impacts of economic reforms made by the CPC under Deng Xiaoping leadership which led, as we have mentioned before, to a huge increase of inward FDI and exports from PR China to all over the world, but mainly to high-income countries (HICs)(Note 1)(World Bank, 2012).

Those four research streams are: "(1) the motives and determinants of FDI to China; (2) 'inside' the 
multinational enterprise (MNE); (3) the impact of MNE activities; and, (4) policy implications for the host country (PR China)" (Fetscherin et al., 2010). Nevertheless, one of these streams, the first one, can be followed, and it is our main research purpose. It is important to add knowledge doing the link between these motives and determinants of FDI and Chinese exports to HICs, with special focus on European Union (EU) countries, which are an important origin of inward FDI and are, at same time, as a group of countries, the most important Chinese trade partner (the Chinese first client market - a unique tariff trade area).

Taking into account 2010 data, and PR China and EU, in the end of the range period studied by Fetscherin, Voss and Gugler (2010), the NOI-Net Outward Investment — ratio was clearly higher than one, and considering the FDI stock, the same ratio has as result a figure higher than ten. Nevertheless, if the FDI flow direction was mainly from EU countries to PR China, the trade flows have more volume from PR China to EU. In $2010 \mathrm{EU}$ has faced a huge trade deficit in the bilateral balance with PR China: more than 156,000 million euros, with an export/import ratio below 0.5 (EUROSTAT, 2011).

Considering our purpose, we have defined as objective the understanding which were the determinants would lead to attract inward FDI and, later, to increase exports from PR China to HICs. An inductive methodology is going to be applied, using the bibliometric method, trying to develop historical streams, relating concepts and research findings within the time period since 1980 until 2010, and giving awareness to the path taken in this field by the Chinese economy.

\section{30 Years of Reforms toward a Global Leadership 1980-2010}

\subsection{Economic Reforms, Inward FDI and Exports}

Several authors, in last decades, have embraced this task: how political and economic reforms were critical issues in order to attract FDI? and, how FDI was related with a vertical approach, where investors were looking for new resources - e.g., labor - in order to export, mainly, manufacturing products to HICs?

Chen, Chang and Zhang (1995) have looked to this topic, relating FDI with Chinese economic development, and, among other conclusions, have highlighted the positive effects perceived, firstly mainly on coastal provinces, and how this positive perception was an important contribution toward a successful political and economic reforms implementation. These authors have given special attention to Deng Xiaoping post-1978 reforms, and underlined how important was the development of Special and Economic Zones (SEZs) - in Guangdong and Fujian provinces. Furthermore, these authors have mentioned the introduction of a law which has created a legal framework to Wholly Owned Subsidiaries (WOS) and moreover a law of FDI encouragement and incentives was approved. Among other reforms, during the 80 's, the joint ventures life-time period was increased and Chinese civil law was changed introducing a new legal framework for foreign-invested enterprises (FIEs) (Chen et al., 1995; Dées, 1998; Cheng \& Kwan, 2000; Tuan \& Fung-Yee Ng, 2002; 2002a; Sun, Tong \& Yu, 2002; Huang, 2003).

Nonetheless, until the mid-1980's, the inward FDI amount was rather limited (OECD, 2000) and highly concentrated within SEZs. During this period, in the first decade post-1978 reforms, Hong Kong (Note2), Macao (Note 3) and Taiwan were the main FDI source, which was called, among others, by Lardy (1996) as 'closed-loop' FDI (or 'round-tripping' FDI). Foreign investors were looking to SEZs as places where they were able to add labor-resources, and then export finished products (Naugthon \& Lardy, 1996). As we mentioned before, an economic development based on inputs expansion (Krugman, 1994), where foreign capital was merged with the local labor-resources. Thus, Dées (1998) has described the late years of the 1980's as a period when inward FDI and exports growth rates were facing a sharply increasing trend.

Tuan and Fung-Yee Ng (2002a; 2006) and Whalley and Xin (2006; 2010) have noted a change in the early-1990s; not only a progressive insertion of local companies in global competition (Chen et al., 1995; Wei, 1995; Naugthon \& Lardy, 1996; Wei, Liu, Parker \& Vaidya, 1999; Zhang \& Song, 2000; Zhang \& Flemingham, 2001; Zhang, 2005), but also a next (new) generation of reforms (Tuan \& Fung-Yee Ng, 2002), reaffirming the open policy, which has led to a diversification of FDI sources, adding to those three overseas Chinese origins (Hong Kong, Macao and Taiwan), other sources, as Europe and United States (Chen, Zhou \& Wan, 2000; Tuan \& Fung-Yee Ng, 2006).

However, this increasing FDI was located mainly at Special Economic Zones (SEZs), and it was the SEZs expansion which has been the basis where these export-led investments were developed (OECD, 2000; Fujita \& $\mathrm{Hu}, 2001)$. Chen et al. (2000), nevertheless, have mentioned the Asian Crisis, in the late 1990s, as an event which has impacted on investors' confidence (Dillip, 2007). Even considering this event, exports were growing in this period; nevertheless, FDI has stopped it raising trend, and decline in the end of the decade (Chen et al., 
2000; World Bank, 2012).

The first decade of the 21 Century was PR China became WTO member, and additional liberal and transparency measures were adopted. In this decade PR China has become the first exporter in the World economy; nonetheless, since 2008, Chinese exports have faced a slowdown, due the uncertainty generated after the Subprime crisis and, the sovereign debt crisis within the Euro Currency Area. Some authors, as mentioned the domestic sources (overseas Chinese territories) as predominant in the time period from 2008 until 2010. The huge decrease in world trade during the year of 2009, and the GDP slowdown in EU countries and in United States are presented as the main reasons for this change (Chiu, 2008; Morrison, 2009; Overholt, 2010).

Liu et al. (2002) have published a research paper where is concluded a causal link between FDI, economic growth and trade. These authors, focusing on the PR China case, have found a "bi-directional casuality" between these variables, which "appear to be mutually reinforcing under the open-door policy". The figures since the early 1980's show a common evolution pattern among these three variables: inward FDI, exports and economic growth (GDP growth as a proxy) - Fig. 1 and Fig. 2.

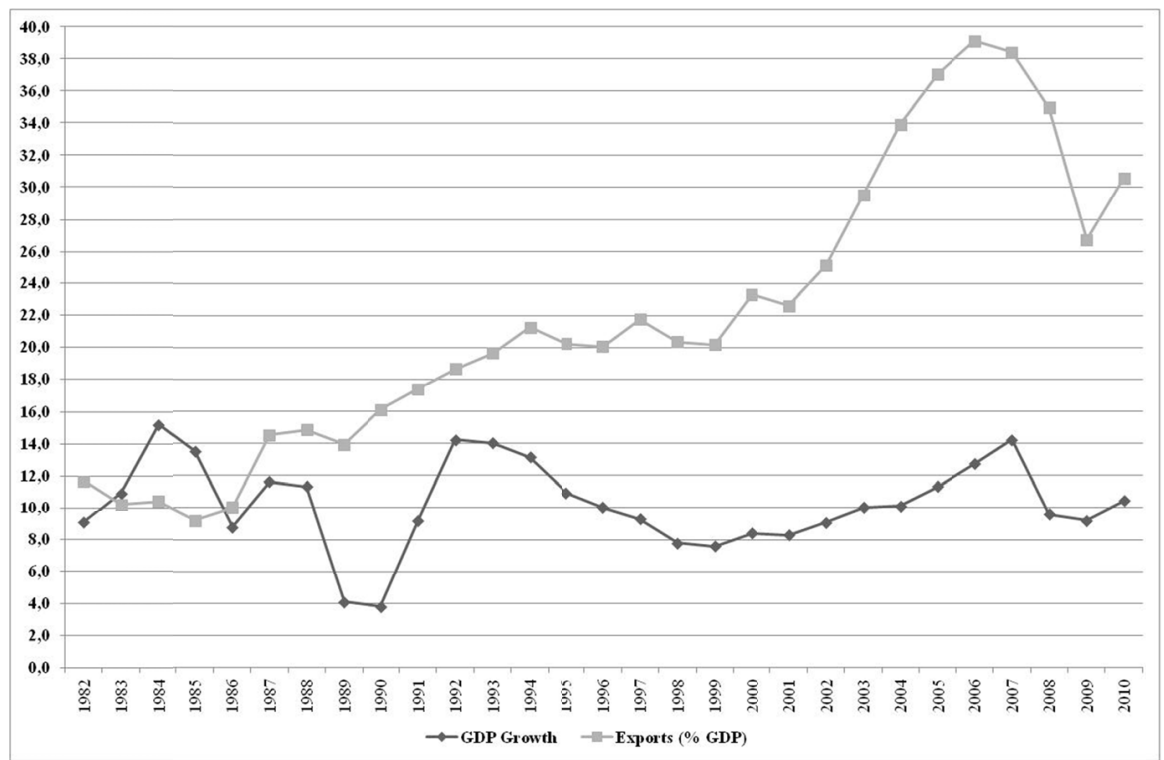

Figure 1. GDP growth and exports (\%GDP) 1982-2010

Data Source: World Bank Database.

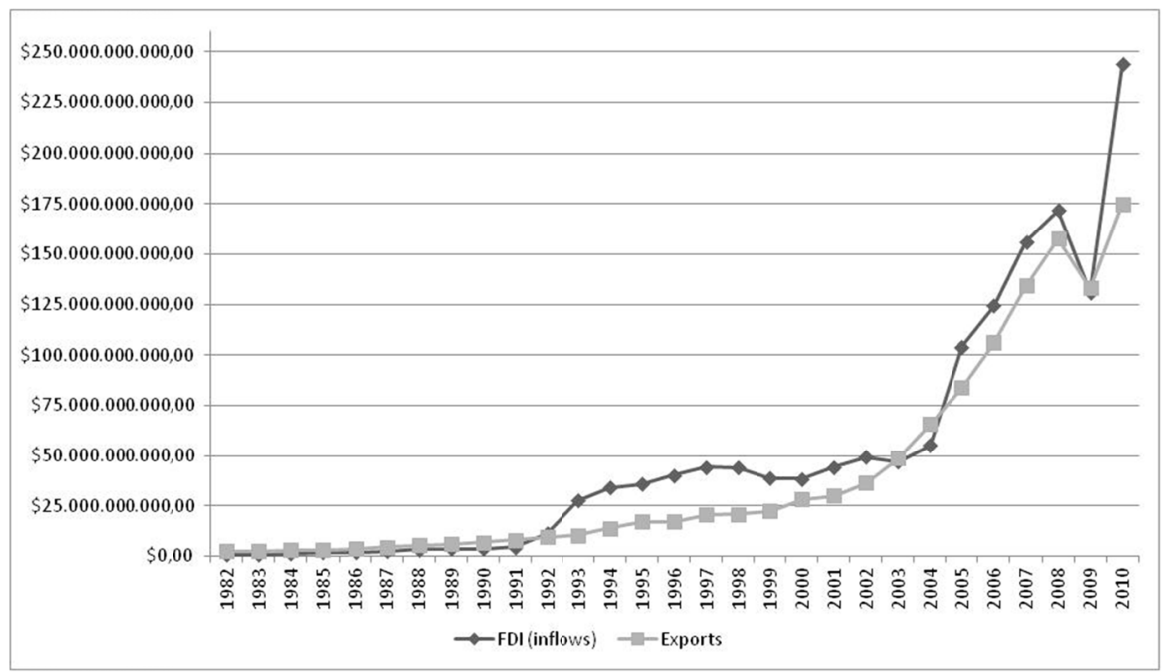

Data Source: World Bank Database.

Figure 2. FDI inflows and exports 1982-2010 


\subsection{Exports Destinations, Imports Origins, Exports Complexity and Inward FDI Sources}

In 2012 PR China is the first exporter and the second importer in the world (EIU, 2011; World Bank, 2012). This leading position was reached in 2009—when the Subprime crisis was hitting the World economy — and in 2012 PR China has exported more than 2 trillion USD, and has imported more than 1.7 trillion USD (EIU, 2011; World Bank, 2012). A surplus of 325 billion USD based on an international trade where the United States, Hong Kong, Japan, South Korea and Germany (an EU country) are the most important clients. These countries are OECD countries, classified by the World Bank as HIC's, and, together, represent $48 \%$ of the PR China goods exports. (Table 1)

Table 1. PR China exporting markets (TOP 5)-\% of the total-ITC statistics, 2012

\begin{tabular}{lllll}
\hline Rank & Markets & 2010 & 2011 & 2012 \\
\hline 1 & United States of America & 18.0 & 17.1 & 17.2 \\
2 & Hong Kong & 13.8 & 14.1 & 15.8 \\
3 & Japan & 7.7 & 7.8 & 7.4 \\
4 & South Korea & 4.4 & 4.4 & 4.3 \\
5 & Germany & 4.3 & 4.0 & 3.4 \\
\hline
\end{tabular}

Additionally, Chinese providers are also HICs, and the Top 5, in 2012, comprises Japan, South Korea, Taiwan, United Sates and Germany. These set of countries represents $40 \%$ of the goods imports into PR China (Table 2).

Table 2. PR China importing markets (TOP 5)-\% of the total-ITC statistics, 2012

\begin{tabular}{lllll}
\hline Rank & Markets & 2010 & 2011 & 2012 \\
\hline 1 & Japan & 12.7 & 11.2 & 10.2 \\
2 & South Korea & 9.9 & 9.3 & 9.5 \\
3 & Taiwan & 8.3 & 7.2 & 7.6 \\
4 & United States of America & 7.4 & 7.1 & 7.4 \\
5 & Germany & 5.3 & 5.3 & 5.3 \\
\hline
\end{tabular}

In an analysis based on goods exported, we find electrical and electronic equipment (487 billion USD), and machinery and nuclear reactors (376 billion USD) as the most important groups of products sent/sold to foreign markets; nevertheless, apparel products, furniture, and optical and photo equipment - as it is shown in Table 3 - are important also, reaching together more than 250 billion USD (ITC Statistics, 2012).

Furthermore, if in the Top 10 of the goods exported we can find mainly industrial goods, when we take a look to imported goods-Table 4-it is important to highlight energy raw materials (minerals fuels, oils and other energy related products), and some other goods, as can be ores, organic chemicals, copper or even oil seed and oleagic fruits, which are mainly raw materials in order to fulfill industrial and manufacturing needs. Nevertheless, electrical and electronic equipment is the group of products which lead the ranking of imported goods Top 10 (381 billion dollars-ITC Statistics, 2012).

Taking into account the previous analysis we should stress a major difference among Chinese exports and PR China imports: even if electrical and electronic equipment is leading both Top10, the exporting goods are mainly manufactured and among importing goods we can find raw materials or other agriculture products. Considering this issue we can identify intra-industry trade, but also an inter-industry trade based on labor abundance in China and a lack of resources - mainly energy and other raw materials - in order to feed or supply the local industry.

It is also important to underline the main industrial sectors in which foreign companies are investing. Taking into account UNCTAD (2012) data, the most important industrial FDI receptors are the following four sectors: 'Chemicals and Chemicals Products', 'Machinery and Equipment', 'Electrical and Electronic Equipment' and 'Motor Vehicles and Other Transport Equipment'. These industrial sectors are also exporting sectors; this element can be indicting a link between inward FDI and PR China exports. 
Table 3. PR China exporting goods (TOP 10)-thousand USD-ITC statistics, 2012

\begin{tabular}{lllll}
\hline Rank & Sector & 2010 & 2011 & 2012 \\
\hline 1 & Electrical, electronic equipment & $388,755,010$ & $445,756,705$ & $487,462,307$ \\
2 & Machinery, nuclear reactors, boilers, etc & $309,813,672$ & $353,763,873$ & $376,002,094$ \\
3 & Articles of apparel, accessories, knit or crochet & $66,710,933$ & $80,164,561$ & $87,059,741$ \\
4 & Furniture, lighting, signs, prefabricated buildings & $50,584,032$ & $59,336,352$ & $77,904,042$ \\
5 & Optical, photo, technical, medical, etc apparatus & $52,109,780$ & $60,684,983$ & $72,816,793$ \\
6 & Articles of apparel, accessories, not knit or crochet & $54,361,478$ & $63,073,873$ & $61,237,963$ \\
7 & Articles of iron or steel & $39,143,621$ & $51,196,168$ & $56,202,059$ \\
8 & Plastics and articles thereof & $34,696,577$ & $45,420,906$ & $55,218,364$ \\
9 & Vehicles other than railway, tramway & $38,397,962$ & $49,539,445$ & $55,174,251$ \\
10 & Footwear, gaiters and the like, parts thereof & $35,633,851$ & $41,722,333$ & $46,817,564$ \\
\hline
\end{tabular}

Table 4. PR China importing goods (TOP 10)-thousand USD-ITC statistics, 2012

\begin{tabular}{lllll}
\hline Rank & Sector & 2010 & 2011 & 2012 \\
\hline 1 & Electrical, electronic equipment & $314,282,498$ & $350,954,252$ & $381,597,419$ \\
2 & Mineral fuels, oils, distillation products, etc & $188,965,812$ & $275,766,337$ & $311,857,463$ \\
3 & Machinery, nuclear reactors, boilers, etc & $172,150,025$ & $199,313,752$ & $181,912,452$ \\
4 & Ores, slag and ash & $109,386,524$ & $150,655,638$ & $133,685,768$ \\
5 & Optical, photo, technical, medical, etc apparatus & $89,919,369$ & $99,140,733$ & $106,369,794$ \\
6 & Vehicles other than railway, tramway & $49,504,235$ & $65,438,574$ & $70,612,733$ \\
7 & Plastics and articles thereof & $63,704,657$ & $70,198,652$ & $69,486,436$ \\
8 & Organic chemicals & $48,263,067$ & $63,131,991$ & $60,921,639$ \\
9 & Copper and articles thereof & $46,183,467$ & $54,251,470$ & $54,607,290$ \\
10 & Oil seed, oleagic fruits, grain, seed, fruit, etc & $27,061,892$ & $32,020,530$ & $38,550,840$ \\
\hline
\end{tabular}

Table 5. Inward FDI sources (TOP 10)-\% of the total-UNCTAD, 2012

\begin{tabular}{lll}
\hline Rank & Country/Origin & 2012 \\
\hline 1 & Hong Kong & 63.8 \\
2 & Japan & 6.6 \\
3 & Singapore & 5.9 \\
4 & Taiwan & 5.5 \\
5 & United States of America & 2.8 \\
6 & South Korea & 2.7 \\
7 & Germany & 1.3 \\
8 & Netherlands & 1.0 \\
9 & United Kingdom & 0.9 \\
\hline 0 & Switzerland & 0.8 \\
\hline
\end{tabular}


The sources of inward FDI are mainly from PR China overseas territories, and foremost from Hong Kong. If we consider also Taiwanese investors, more than two thirds of the FDI attracted are from these overseas Chinese territories. A 'closed-loop' FDI, where Chinese investors or companies located at Hong Kong, Macao and Taiwan invest in the PR China mainland. Nonetheless, if we exclude this 'closed-loop' FDI, the main FDI sources are HICs - Japan, Singapore, South Korea, United States of America and other HICs from the EU. The TOP10 origins/sources, together, represent $91.3 \%$ of the PR China inward FDI-Table 5.

\section{Method and Results: Bibliometric Method Applied to PR China Inward and Exports to HICs}

\subsection{Bibliometric Method}

The bibliometric citation analysis illustrates linkages between research publications, authors and specific topics. Their importance is shown by a local or global citation score (LCS and GCS). This research method is based on the assumption that researchers publish their most important findings; their research is based predominantly on other, previously published, materials (Borgman \& Furner, 2002; Van Raan, 2003). The analysis' unit is a citation (Kim \& McMillan, 2008). This method goes beyond counting publications (Quer, Claver \& Rienda, 2007): identify publications' concentration centers that 'map out' research streams (Kim \& McMillan, 2008).

Data for our research was collected in February/March 2012 from the ISI Web of Knowledge database. It provides an opportunity to use the Social Sciences Citation Index (SSCI). The purpose of this program is to collect only English written research papers. The author's search period was from 1980 until 2012 to coincide with the major changes and improvements in the Chinese economy, after the conclusions of the Third Plenary Session of the 11th CPC Central Committee, in 1978, when have begun the new reforms and opening policy.

During the search period, the type of publication was not specified, giving more focus on a topic overview. In order to collect comprehensive data, have been specified a more detailed search classification. The search combinations included: 'Inward FDI in China'; 'Chinese export to the EU'; and 'China-EU relations'. A criteria 'FDI impact on export' was added to improve quality of research. Our main objective when was selected EU as target market was to focus on a specific market — or tariff trade area-where we can find the large majority of HICs, and, as it was mentioned before, together, EU member-states, are the most important PR China client.

The search result find 300 research papers, and were added 67 publications were added manually, when was concluded a more deep analysis based on the previous 300. Total authors' amount was 547 and, among them, 7 are anonymous. These 367 articles were published in 229 journals. Their total citation amount is 8080 references (TGCS). In order to identify these references was used the HistCite software, where research papers can be observed and related by author, date or journal type. Local and Global Citation Score (LCS and GCS) have been the key indicators in order to evaluate the relevance of each research paper of our sample. An approach considering the average citation per year was used also (LCS/t and GCS/t).

The Local Citation Score (LCS) shows the number of times the research paper has been cited within the sample-our sample is 367 research papers collected; the Global Citation Score (GCS) shows the number of times the research paper has been cited in the ISI Web of Science (Garfield, Pudovkin \& Istomin 2003); LCS/t is the Local Citation Score per year from research paper publication to the end of the sample period; and, GCS/t is the Global Citation Score per year from research paper publication to the end of the sample period (Fetscherin et al., 2010). Taking into account our purpose, our analysis it was made mainly considering local citations (journals and research papers).

\subsection{Most Influential Journals}

The 367 publications of our sample can be subdivided into three main categories: economics (30.9\%); international management and development (25.4\%); and regional studies (China) (20.3\%). These subdivisions are together $76.6 \%$ of our sample publications. Among them there are six journals that got a total local citation score - LCS based on author or journal criteria — over 13. These journals are: Journal of International Business Studies (20); Applied Economics (18); China Economic Review (17); Journal of International Economics (17); World Development (14); and, Regional Studies (13) (see Table 1).

The top 20 publications representing $28.3 \%$ of our sample publications and among them we can find $15.86 \%$ of cross-citations, and $22.62 \%$ of all local citations. The Journal of International Business Studies (JIBS) is the most cited journal; other previous studies, about the same topic (Fetscherin et al., 2010), conclude also that JIBS is highly cited journal. 
Table 6. Ranking the influential journals_-TLCS (total local citation score) and TLCS/t

\begin{tabular}{|c|c|c|c|}
\hline Rank & Journal & TLCS & $\mathrm{TLCS} / \mathrm{t}$ \\
\hline 1 & China Economic Review & 17 & 2.29 \\
\hline 2 & Applied Economics & 18 & 2.10 \\
\hline 3 & Journal of International Business Studies & 20 & 2.05 \\
\hline 4 & Journal of International Economics & 17 & 1.13 \\
\hline 5 & China \& World Economy & 7 & 1.11 \\
\hline 6 & Applied Geography & 1 & 1.00 \\
\hline 7 & Regional Studies & 13 & 0.98 \\
\hline 8 & World Development & 14 & 0.78 \\
\hline 9 & Journal of Development Studies & 8 & 0.59 \\
\hline 10 & Foreign Affairs & 5 & 0.56 \\
\hline 11 & Eurasian Geography and Economics & 2 & 0.46 \\
\hline 12 & Journal of World Trade & 2 & 0.40 \\
\hline 13 & Annals of Regional Science & 4 & 0.33 \\
\hline 14 & China Agricultural Economic Review & 1 & 0.33 \\
\hline 15 & Contemporary Economic Policy & 4 & 0.33 \\
\hline 16 & Journal of Business Economics and Management & 1 & 0.33 \\
\hline 17 & Journal of Comparative Economics & 2 & 0.33 \\
\hline 18 & Economics of Planning & 4 & 0.27 \\
\hline 19 & Economics of Transition & 3 & 0.25 \\
\hline 20 & Management International Review & 1 & 0.25 \\
\hline
\end{tabular}

\subsection{Historiographic Research Papers' Citation Mapping}

Histographic bibliometric citation mapping was used in order to understand better the links between research papers published (see Figure 3); the vertical axis represents the year and the number of published papers in that year (in parentheses). Only research papers with a LCS higher or equal to 5 were considered. Each map node displays a research node; it can be seen as a concentration of information, or 'hub' (Garfield et al., 2003; Fetscherin et al., 2010). The node size is relative to the number of received local citations and larger squares illustrate more cited publications. Arrows from one node to another denote a citation relationship between papers and research papers without an arrow pointing towards them are not cited by any other paper of the sample (only 10 research paper with a LCS higher or equal to 5). There are three nodes without connectivity in our picture: Buckley et al., 2002; Gilboy, 2004; and Rodrik, 2006 (see Figure 3). 


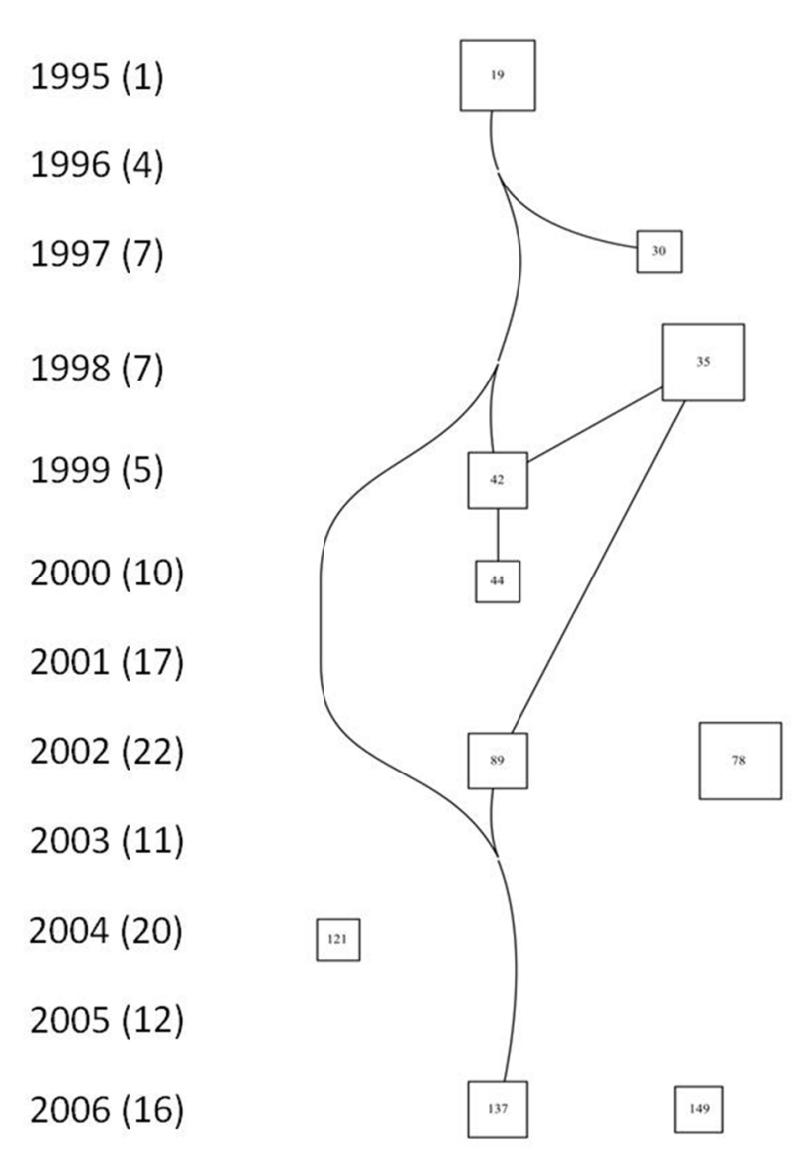

(19) Chen et al (1995): a link betwwen FDI and economic reforms is made; FDI is related with economic growth and the increasing of total fixed asset investment in China. A number of domestic companies is forced to compete globaly.

(30) De Mello (1997): focused on inward FDI and its impacts on economic growth; presents FDI as a bundle of capital stocks, know-how and technology; and, conclude also "FDI leads to increasing retums in domestic production, and increases the value content of FDI-related production"

(35) Bor ensztein et al (1998): FDI as a tool in order to transfer technology among developed and developing countries; suggests that FDI contributes more than domestic investment to economic growth, but only if the host country has the absorptive capability of the advanced technologies.

(42) Wei et al (1999): this author concluded "Frovinces with a higher level of international trade, lower wage rates, more R\&D manpower, higher GDP growth rates, quicker improvement in infrastructure, more rapid advances in agglomeration, more preferential policies and closer ethnic links with overseas Chinese attract relatively more pledged FDI".

(44) Zhang and Song (2000): FDI is increasing sirce the late 70's, due the opendoor policy; " (...) there is a considerable evidence on the FDI export linkage in China", (..) findings support the widely held belief that increased levels of FDI positively affect provincial manufacturing export performance.

(78) Buckley et al (2002): using data from 1995, "non-Chinese MNEs are found to generate technological and intemational marke: access spillover benefits for Chinese firms, while overseas Chinese investor: confer only market access benefits. “

(89) Liu et al (2002): the author finds "bi-directional causality between economic growth, FDI and exports. Economic development, exports and FDI appear to be mutally reinforcing under the open-door policy."

(121) Gilboy (2004): the author finds "Washington need not worry about China's economic boom, much less respond with protectionism. Although China controls more of the world's exports than ever before, its high-retum high-tech industries are dominated by foreign companies"

(137) Yao (2006): the author finds "The results suggest that two development policies adopted in China are useful for other developing and transitional economies: export promotion and adoption of world technology and business practices."

(149) Rodrik (2006): the author finds "(..) China has ended up with an export basket that is significantly more sophisticated than what would be normally expected for a country at its income level. (..); China's future growth is not the volume of exports, but whether China will continue to latch on to higher-income products over time."

Figure 3. Citation mapping 1980-2010; LCS $>$ or equal than 5

Source: ISI, Web of Knowledge (2012).

Two main streams were found as results by applying the bibliometric method. A first stream where from the research paper published by Chen et al. (1995) is developed a path where is made a link between economic reforms and FDI attraction, and is given to FDI an important role in the increasing of total assets (capital goods) in PR China. Chen, Chang and Zhang (1995) contribution was important when authors as Wei et al. (1999) and Zhang and Song (2000) have related inward FDI with provinces where lower wages (labor), infrastructures and R\&D manpower were found as available resources characteristics (or features). A linkage between FDI and exports - and manufacturing provinces performance — is also made, and Liu et al. (2002) finds a bi-directional relation among FDI, exports and economic development, showing a mutual reinforcing positive impact. Later, Yao (2006) has concluded, as a learning process, that those PR China policies toward export promotion and the adoption of business best practices would be useful for other transitional economies. This first stream links economic reforms, economic policies toward FDI attraction and FDI export-driven, resources that were sought in order to be added to foreign technology and international market access knowledge (owned by FIEs) - Figure 3a. A second stream is also shown as result, where it is developed, over the time range 1980-2010, the contribution of FDI - mainly from HICs - in order to contribute to a more value-added export basket. Even if we don't find a direct link between the research papers, from Chen's et al. (1995) contribution another set of research papers has been published focusing how MNEs from HICs has made an important contribution in order to involve domestic companies in the global economy. De Mello (1997) has focused how FDI impacts on domestic companies performance, and how increases the value of FDI-related production. Borenztein et al. (1998) has given an additional contribution, relating FDI with a more impact on economic growth than the domestic investment. Nevertheless, Borenztein et al. (1998) contribution is also important in another dimension: it has been made a direct relation among FDI impact - and effectiveness in economic growth impact-with the absorptive capability of the host country. It means, the impact of FDI in the economic growth, and in the export performance, is related with the context, and SEZs in PR China have performed an important role.

Buckley, Clegg and Wang (2002) have made a difference between FDI which had origin in HICs or in overseas 
Chinese territories (Hong Kong, Taiwan and Macao). These authors have found that MNEs from HICs generate more technological spillovers than overseas Chinese investors, adding more value to FDI related production, and leveraging technological and other knowledge capabilities of domestic companies. Rodrik (2006) concludes later that the Chinese export basket is more sophisticated than it would be expected for a country with its income level. This difference is a result - $\mathrm{a}$ final result —of an economic policy toward an export-driven FDI attraction, where HICs have performed an important role, leveraging domestic companies, contributing with international markets knowledge and high-tech products and technologies. These investment flows were possible because economic reforms were made, and HICs which are the main non-Chinese FDI investors, have faced local resources (e.g., labor) which were added to their capital and knowledge resources-Figure 3a.

Additionally, even if this paper is not aligned in the previous stream-Figures 3 and $3 \mathrm{a}-$ Gilboy (2004) published in the Foreign Affairs an article where mention how Chinese high-tech exports are made by FIEs from HICs. Reinforcing this issue, Gilboy (2004) states: "high-tech companies are dominated by foreign companies". And foreign companies, in high-tech industries are mainly from HICs.

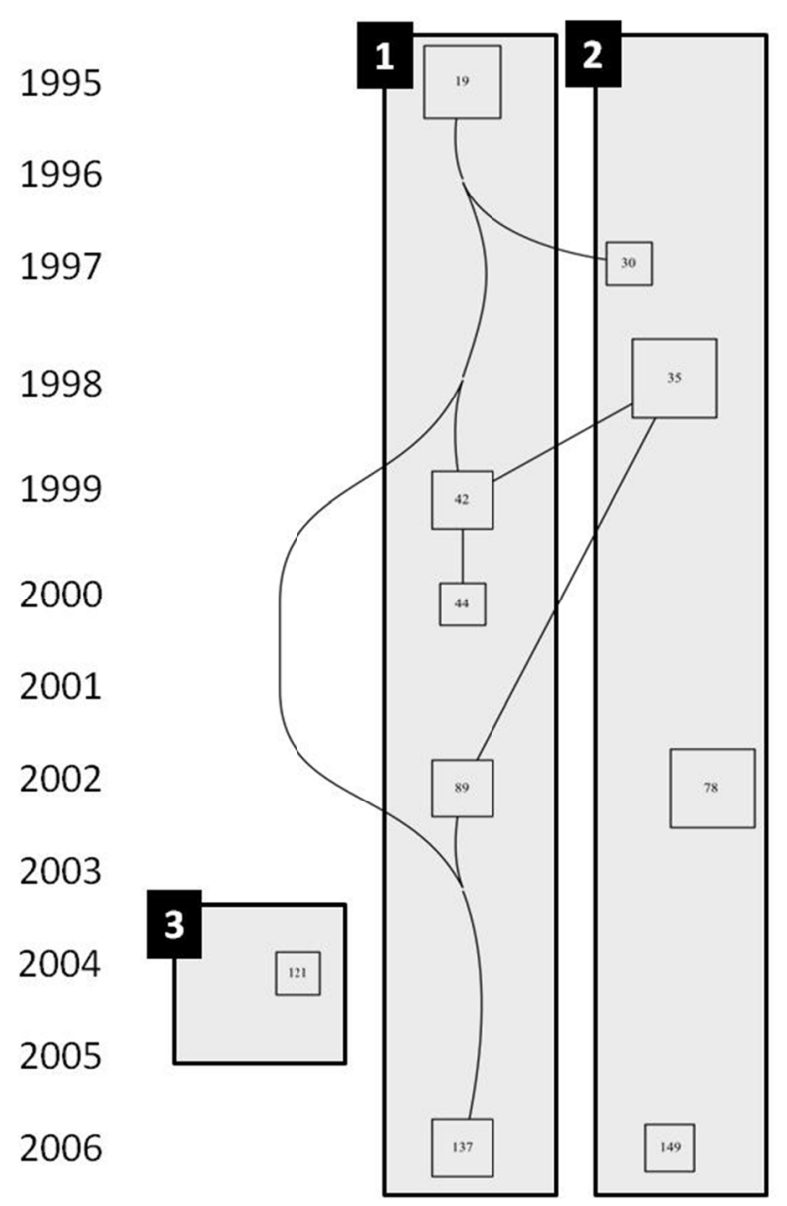

(19) Chen et al (1995): a link betwwen FDI and economic reforms is made; FDI is related with economic growth and the increasing of total fixed asset investment in China. A number of domestic companies is forced to compete globaly

(30) De Mello (1997): focused on inward FDI and its impacts on economic growth; presents FDI as a bundle of capital stocks, know-how and technology and, conclude also "FDI leads to increasing retums in domestic production, and increases the value content of FDI-related production".

(35) Bor ensztein et al (1998): FDI as a tool in order to transfer technology among developed and developing countries; suggests that FDI contributes more than domestic investment to economic growth, but only if the host country has the absorptive capability of the advanced technologies.

(42) Wei et al (1999): this author concluded "Provinces with a higher level of international trade, lower wage rates, more R\&D manpower, higher GDP growth rates, quicker improvement in infrastructure, more rapid advances in agglomeration, more preferential policies and closer ethnic links with overseas Chinese attract relatively more pledged FDI".

(44) Zhang and Song (2000): FDI is increasing since the late 70's, due the opendoor policy; " $(\ldots)$ there is a considerable evidence on the FDI export linkage in China"; (..) findings support the widely held belief that increased levels of FDI positively affect provincial manufacturing export performance.

(78) Buckley et al (2002): using data from 1995, "non-Chinese MNEs are found to generate technological and intemational market access spillover benefits for Chinese firms, while overseas Chinese investors confer only market access benefits. “

(89) Liu et al (2002): the author finds "bi-directional causality between economic growth, FDI and exports. Economic development, exports and FDI appear to be mutually reinforcing under the open-door policy."

(121) Gilboy (2004): the author finds "Washington need not worry about China's economic boom, much less respond with protectionism. Although China controls more of the world's exports than ever before, its high-retum high-tech industries are dominated by foreign companies"

(137) Yao (2006): the author finds "The results suggest that two development policies adopted in China are useful for other developing and transitional economies: export promotion and adoption of world technology and business practices."

(149) Rodrik (2006): the author finds "(...) China has ended up with an export basket that is significantly more sophisticated than what would be normally expected for a country at its income level. (..); China's future growth is not the volume of exports, but whether China will continue to latch on to higher-income products over time."

Figure 3a. Citation mapping 1980-2010; LCS > or equal than 5

Source: ISI, Web of Knowledge (2012)—A Cluster Analysis.

(1) Economic reforms toward an inward FDI attraction and world exports leadership

(2) Inward FDI led to an increasing value of the exports basket

(3) Foreign companies dominate high-tech industries and a lion's part of Chinese industrial exports

\section{Discussion: Lessons Learned from China}

Yao (2006) has concluded how Chinese case can be a learning case for other transitional economies. During the last 30 years PR China has been facing a huge increase of inward FDI and exports. A commercial surplus and an important inward FDI stock is the result of a strategy where economic openness to foreign investors, the building of agglomeration economies (e.g., SEZs) and the FDI-spillovers management were key-factors in order to reach the current world export ranking leadership. 
Based on the bibliometric method, and on the literature review, it was possible to find how this phenomenon has been studied, and how researchers have published in the most influential journals, and which have been cited by several authors in a cumulative process of adding knowledge about this topic.

Since 1978, PR China has been implementing economic reforms; those reforms were crucial to activate endogenous resources. A disclosure of local resources which have been used by foreign investors, in order to produce goods in extended value chains (global value chains-Buckley \& Casson, 2002; 2011; Humphrey, Schmidt, 2002; 2004). But those reforms were based on a policy choice, where 'one country, two systems' was the main reference.

Firstly, because PR China has developed agglomeration economies; even if some political issues can be raised regarding this option, besides that it was a policy which has given to foreign investors a location where their ownership advantages would be better exploited. SEZs were locations where labor abundance has been joined with knowledge and other resources. It has been important also the reforms made on legislation about taxes and joint-ventures. Those reforms and the previous mentioned agglomeration economies were important when global trade policy was moving toward a more liberal approach; the ending of the Uruguay Round, and all the efforts made during the last decades have developed a context where vertical FDI - and other sort of quasi-hierarchy approaches (Humphrey \& Schmitz, 2003; 2004) - is being used as a tool to improve value chain efficiency. PR China, even if as it was stated by Wei et al. (1999) this approach has led to an uneven development between coastal provinces and non-coastal provinces. Nevertheless, Wei et al. (1999) contribution goes beyond this statement, and is important to highlight how this author underlines the importance of infrastructures, more R\&D human resources and a closer link with overseas Chinese community. Those issues were critical to attract more inward FDI; and this policy was also critical in order to create a better involvement of local companies in international trade (mainly exports).

These SEZs were locations where it was possible to develop more efficient backward linkages, promoting an efficient context where FDI would find a better emplacement for its success. A location which was competitive in order to attract FDI, and at same time which was developing local companies competitiveness, with absorptive capabilities; a set of local companies which was able to get and transform the knowledge transferred by MNEs from HICs in new products and services that are competing not locally but in global markets.

A differentiation must be made among foreign investors: two groups have emerged, one where we can find overseas Chinese investors, and another, where are mainly investors from HICs. Buckley et al. (2002) has given an important contribution, as we have mentioned before, when differentiates the spillover effects from inward FDI which had as source HICs: this group of investors not only has brought market access to PR China exports, but also has generated technological spillovers, increasing the production-value content (Buckley et al., 2007)

This bundle of capital and knowledge is a key factor when, as it was concluded by Rodrik (2006), PR China exports basket was more value-added than it would be expected; and when we relate inward FDI sources, goods exported and PR China export-markets, we can find HICs as source, more value-added products, where are predominat manufacturing goods, and USA and EU as most important clients (among other HICs) - see Figure 4.

Since 1978 steps were taken in order to capture FDI focused on exports, as a lever of economic growth. HICs as source of FDI, looking for resources in order to improve the value chain efficiency, and at same time HICs as most important export markets. Even if the 'closed-loop' FDI - or round-tripping FDI - as played an important role as FDI source, HICs have been actors which led PR China to the world export ranking leadership. 


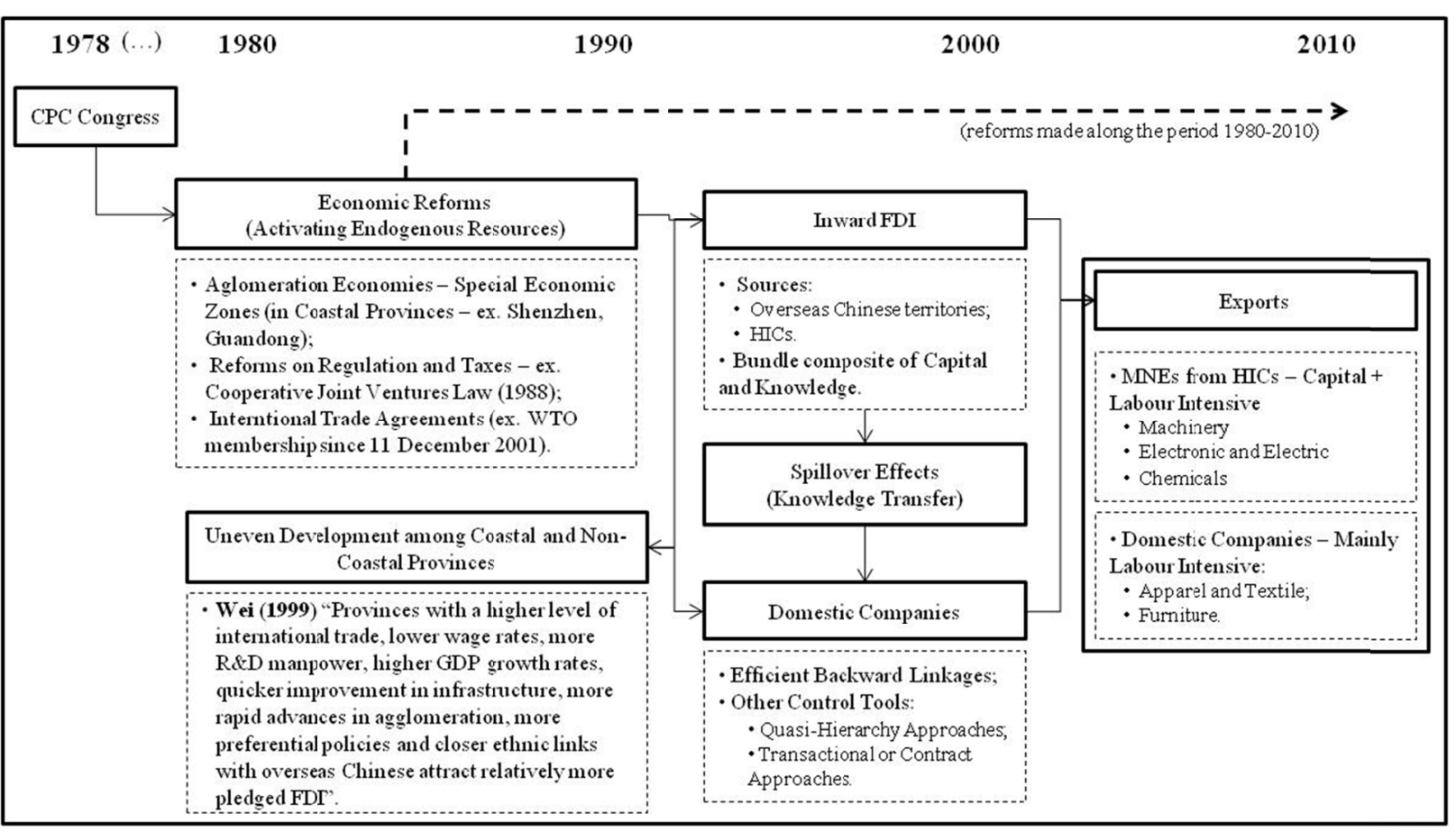

Figure 4. Lessons learned from PR China—30 years building a world exports leadership

\section{Conclusion}

Our purpose was the understanding of which were the determinants would lead to attract inward FDI and, later, to increase exports from PR China to HICs. Using the bibliometric method in an historical perspective we have focused on inward FDI attraction and how it has impacted on PR China exports.

PR China inward FDI sources are mainly overseas Chinese investors and investors from HICs; and, the most important export markets are United States and EU (28 member-states). The importance of HICs as FDI source which played a knowledge transfer role was highlighted by Buckley et al. (2002), and other authors have concluded how relevant it was in order to improve the value of Chinese exports.

From the method three main determinants were identified: PR China has implemented since 1978, and is a on-going process, a huge number of reforms, which had as objective the attraction of inward FDI export-driven; HICs have invested in manufacturing industries, which are the main Chinese export sectors; and, as it was stated by Gilboy (2004), foreigners from HICs are the main owners of the most knowledge-intensive - high-tech — companies in PR China (and at same time exporting companies).

The historical perspective gives us an insight about the policy choices made in order to achieve the leadership; and reforms made during the last 30 years in order to develop agglomeration economies (SEZs), a legislation reform in order to reduce taxes, promote FIEs and joint-ventures, have created a context where endogenous resources (mainly labor resources) became 'available' and open to be used by investors-from HICs and overseas Chinese territories.

This step was crucial in order to initiate a process where inward FDI export-driven and exports are mutually reinforcing, generating economic growth (and employment) - Liu et al. (2002).

Finally, if the export basket has a value content higher than it is expected (Rodrik, 2006), is related with HICs investors, but also because the vertical approach, where the value chain is extended, assuming an international/global perspective. Symmetric flows: FDI from HICs to PR China and exports-mainly manufacturing goods - from PR China to HICs.

Further steps can be taken in this field. The lessons learned from the PR China case can be compared with other cases; for instance, with other BRICs. Brazil is the second BRICs which receives more inward FDI, and is going to be our next research object, applying the same inductive methodology, trying to understand if the evolution of Brazil, during the last three decades, has been the same, with the same features than the Chinese case. 


\section{References}

Borensztein, E., Gregório, J., \& Lee, J. W. (1998). How does foreign direct investment affect economic growth? Journal of International Economics, 45(1), 115-135. http://dx.doi.org/10.1016/S0022-1996(97)00033-0

Borgman, C. L., \& Furner, J. (2002). Scholarly Communication and Bibliometrics. In I. B. Cronin (Ed.), Annual Review of Information Science and Technology (Vol. 36, pp. 2-72). http://dx.doi.org/10.1002/aris.1440360102

Buckley, P., \& Casson, M. (1976). The Future of the Multinational Enterprise. Basingstoke and London: Macmillan.

Buckley, P., \& Casson, M. (2011). Marketing and the multinational: extending internalization theory. Journal of the Academy of Marketing Science, 39, 492-508. http://dx.doi.org/10.1007/s11747-010-0243-0

Buckley, P., Clegg, J., \& Wang, C. (2002). The impact of inward FDI on the performance of Chinese manufacturing firms. Journal of International Business Studies, 33(4), 637-655. http://dx.doi.org/10.1057/palgrave.jibs.8491037

Buckley, P., Clegg, J., \& Wang, C. (2007). Is the relationship between inward FDI and spillover effects linear?-An empirical examination of the case of China. Journal of International Business Studies, 38(3), 447-459. http://dx.doi.org/10.1057/palgrave.jibs.8400274

Chen, C., Chang, L., \& Zhang, Y. M. (1995). The role of foreign Direct Investment in China post-1978 Economic Development. World Development, 23(4), 691-703. http://dx.doi.org/10.1016/0305-750X(94)00143-M

Chen, L., Zhou, Z., \& Wan, G. (2000). Why is U.S. direct investment in China so small? Contemporary Economic Policy, 18(1), 95-106. http://dx.doi.org /10.1111/j.1465-7287.2000.tb00008.x

Cheng, L., \& Kwan, Y. (2000). What are the determinants of the location of foreign direct investment? The Chinese experience. Journal of International Economics, 51, 379-400. http://dx.doi.org/10.1016/S0022-1996(99)00032-X

Chiu, L. (2008). China's Response to the Global Financial Crisis. Retrieved from http://chineseculture.about.com/od/thechinesegovernment/a/Chinaeconomy.htm

De Mello, L. (1997). FDI in developing countries and growth, a selective survey. Journal of Development Studies, 34(1), 1-34. http://dx.doi.org /10.1080/00220389708422501

Dées, S. (1998). FDI in China, determinants and effects. Economics of Planning, 31(2-3), 175-194. http://dx.doi.org/10.1023/A:1003576930461

Dilip, K. (2007). Foreign Direct Investment in China: It's Impact on the Neighboring Asian Economies. Asian Business \& Management, 6, 285-301. http://dx.doi.org/10.1057/palgrave.abm.9200225

Dunning, J. (2003). The role of foreign direct investment in upgrading China's competitiveness. Journal of International Business and Economy, 4(1), 1-13.

EIU-Economic Intelligence Unit. (2012). Country Data. Retrieved from http://country.eiu.com/China

Fetscherin, M., Voss H., \& Gugler, P. (2010). 30 Years of FDI in China, an interdisciplinary literature review. International Business Review, 19(3), 235-246. http://dx.doi.org/10.1016/j.ibusrev.2009.12.002

Fujita, M., \& Hu, D. (2001). Regional disparity in China 1985-1994, The effects of globalization and economic liberalization. Annals of Regional Science, 35(1), 3-37. http://dx.doi.org /10.1007/s001680000020

Garfield, E., Pudovkin, A., \& Istomin, V. (2003). Why do we need algorithmic historiography? Journal of the American Society for Information Science and Technology, 54(5), 400-412. http://dx.doi.org/10.1002/asi.10226

Gilboy, G. (2004). The myth behind China's miracle. Foreign Affairs, 83(4), 33-48. http://dx.doi.org/10.2307/20034045

Huang, Y. (2003). Selling China: Foreign Direct Investment during the Reform Era. Cambridge.

Humphrey, J., \& Schmitz, H. (2002). How Does Insertion in Global Value Chains Affect Upgrading in Industrial Clusters? Regional Studies, 36(9), 1017-1027. http://dx.doi.org/10.4337/9781843769743.00020

Humphrey, J., \& Schmitz, H. (2004). Chain governance and upgrading: taking stock. In Schmitz, H. (Ed.), Local Enterprises in the Global Economy: Issues of Governance and Upgrading (pp. 349-381). Cheltenham: 
Elgar. http://dx.doi.org/ 10.1093/jnlecg/lbh066

ITC-International Trade Center. (2012). Country Data —China. Retrieved from http://www.intracen.org

Kim, J., \& McMillan, S. (2008). Evaluation of internet advertising research-A bibliometric analysis of citations from key sources. Journal of Advertising, 37(1), 99-112. http://dx.doi.org/ 10.2753/JOA0091-3367370108

Krugman, P. (1994). The Myth of East Asia's Miracle. Foreign Affairs, 62-78. http://dx.doi.org/10.2307/20046929

Lardy, N. (1996). The Role of Foreign Trade and Investment in China's Economic Transformation. In A. Walder (Ed.), China's Transitional Economy. Oxford: Oxford University Press.

Liu, X., Burridge, P., \& Sinclair, P. (2002). Relationships between economic growth, FDI and trade, evidence from China. Applied Economics, 34(11), 1433-1440. http://dx.doi.org/10.1080/00036840110100835

Markusen, J. (1995). The boundaries of multinational enterprises and the theory of international trade. The Journal of Economic Perspectives, 9(2), 169-189. http://dx.doi.org/ 10.1257/jep.9.2.169

Morrison, W. (2009). China and the Global Financial Crisis: Implications for the United States. Congressional Research Service. Washington DC.

Naughton, B., \& Lardy, N. (1996). China's Emergence and Prospects as a Trading Nation. Brookings Papers Economic Activity, 1996(2), 273-344. http://dx.doi.org/10.2307/2534623

OECD. (2000). Main Determinants and Impacts of Foreign Direct Investment on China's Economy. OECD Working Papers on International Investment, 2000(4). OECD Publishing. http://dx.doi.org/10.1787/321677880185

Overholt, W. (2010). China in the global financial crisis: rising influence, rising challenges. The Washington Quarterly, 33(1), 21-34. http://dx.doi.org/10.1080/01636600903418652

Quer, D., Claver, E., \& Rienda, L. (2007). Business and management in China: a review of empirical research in leading international journals. Asian Pacific Journal of Management, 24, 359-384. http://dx.doi.org/10.1007/s10490-007-9040-9

Rodrik, D. (2006). What's so special about China's exports? China \& World Economy, 14(5), 1-19. http://dx.doi.org/10.1111/j.1749-124X.2006.00038.x

Sun, Q., Tong, W., \& Yu, Q. (2002). Determinants of foreign direct investment across China. Journal of International Money and Finance, 21(1), 79-113. http://dx.doi.org/10.1016/S0261-5606(01)00032-8

Tuan, C., \& Fung-Yee Ng, L. (2002). FDI in China and the Regional Development: From Institutional Reform to agglomeration Economics Perspectives. Proceeding of 1st International Conference on National State and Economic Policy: Conflict and Cooperation. Japan.

Tuan, C., \& Fung-Yee Ng, L. (2002a). FDI Facilitated by Agglomeration Economies: Evidence from Manufacturing and Services Joint Ventures. Journal of Asian Economies, 13(6), 749-765. http://dx.doi.org/10.1016/S1049-0078(02)00183-5

Tuan, C., \& Fung-Yee Ng, L. (2006). FDI Inflows and Growth of Private Business in China. Journal of Entrepreneurship Research, 9(1), 101-132.

UNCTAD. (2012). UNCTAD FDI Statistics-Investment Country Profiles. United Nations. Retrieved from http://www.unctad.org

Van Raan. (2003). The use of bibliometric analysis in research performance assessment and monitoring of interdisciplinary scientific developments. Technikfolgenabschätzung, 12(1), 20-29.

Wei, S. (1995). Attracting foreign direct investment: Has China reached its potential? China Economic Review, 6(2), 187-199. http://dx.doi.org/10.1016/1043-951X(95)90003-9

Wei, Y., Liu, X., Parker, D., \& Vaidya, K. (1999). The regional distribution of FDI in China. Regional Studies, 33(9), 857-867. http://dx.doi.org/10.1080/00343409950075498

Whalley, J., \& Xin, X. (2006). China's FDI and non-FDI economies and the sustainability of future high Chinese growth. NBER Working Paper. http://dx.doi.org/10.3386/w12249

Whalley, J., \& Xin, X. (2010). China's FDI and non-FDI economies and the sustainability of future high Chinese growth. China Economic Review, 21(1), 123-135. http://dx.doi.org/10.1016/j.chieco.2009.11.004

World Bank. (2012). World Development Indicators. Retrieved from http://data.worldbank.org/ 
Yao, S. (2006). On economic growth, FDI and exports in China. Applied Economics, 38(3), 339-351. http://dx.doi.org/10.1080/00036840500368730

Zhang, K. (2005). How Does FDI Affect a Host Country's Export Performance? The case of China. International Conference of WTO, China, and the Asian Economies, 3, 25-26.

Zhang, K., \& Song, S. (2000). Promotion exports the role of inward FDI in China. China Economic Review, 11(4), 385-396. http://dx.doi.org/10.1016/S1043-951X(01)00033-5

Zhang, Q., \& Flemingham, B. (2001). The relationship between inward FDI and China's provincial export trade. China Economic Review, 12(1), 82-99. http://dx.doi.org/10.1016/S1043-951X(01)00044-X

\section{Notes}

Note 1. World Bank (2012): a high-income country is defined as country with a GNI per capita of US\$12,480 or more (range defined considering 2011).

Note 2. Hong-Kong was a Chinese territory under British Administration. The Handover was in 1997.

Note 3. Macao was a Chinese territory under Portuguese Administration. The Handover was in 1999.

\section{Copyrights}

Copyright for this article is retained by the author(s), with first publication rights granted to the journal.

This is an open-access article distributed under the terms and conditions of the Creative Commons Attribution license (http://creativecommons.org/licenses/by/3.0/). 